\title{
The eelgrass canopy: an above-bottom refuge from benthic predators for juvenile bay scallops Argopecten irradians*
}

\author{
David G. Pohle, V. Monica Bricelj** , Zaúl García-Esquivel \\ Marine Sciences Research Center, State University of New York, Stony Brook, New York 11794-5000, USA
}

\begin{abstract}
Juvenile bay scallops Argopecten irradians commonly attach to shoots of eelgrass Zostera marina using byssal threads. Although this behavior has long been recognized, its adaptive value is poorly understood. This study examined (1) the size-specific nature of scallop attachment on eelgrass, and (2) the possible role of vertical attachment in providing refuge from benthic predators. Laboratory experiments using artificial eelgrass showed strong, inverse relationships between scallop size (over the range 6 to $20 \mathrm{~mm}$ ) and several measures of attachment performance (percent attachment, rate of attachment, and height-above-bottom attained). Field experiments in which 10 to $15 \mathrm{~mm}$ scallops were tethered to natural eelgrass in Lake Montauk, Long Island, New York (USA), demonstrated a dramatic, highly significant enhancement of scallop survival at greater heights of attachment. Scallops tethered at 20 to $35 \mathrm{~cm}$ above bottom experienced $>59 \%$ survival over $4 \mathrm{~d}$, compared to $<11 \%$ survival near the sediment surface. A similar pattern was observed in laboratory tethering experiments using transplanted natural eelgrass and 3 crab predators common in mid-Atlantic embayments: Carcinus maenas, Libinia dubia, and Dyspanopeus sayi. The refuge value of vertical attachment was found, however, to be less with $D$. sayi than with the other predators tested, since individuals of this species climbed eelgrass to feed on scallops in the upper canopy. These data demonstrate that vertical attachment on eelgrass functions as an effective predator-avoidance mechanism for juvenile bay scallops by placing them out of reach of many benthic predators. It has also been previously shown that scallop predatory risk decreases with scallop size, with a partial size refuge attained at about $40 \mathrm{~mm}$. It is therefore suggested that scallops undergo an ontogenetic shift from a spatial to a size refuge from predation as they move from the eelgrass canopy to the sediment surface over the course of their post-settlement life history. We hypothesize that this shift may result in a critical window of high predatory risk between ca 15 and $40 \mathrm{~mm}$, when scallops are expected to be most susceptible to benthic predators.
\end{abstract}

\section{INTRODUCTION}

Enhanced faunal densities within seagrass beds relative to those in unvegetated substrate have been reported for a variety of benthic species, both infaunal and epifaunal (reviewed by Orth et al. 1984). This enhancement has been attributed to active habitat selection (Leber 1985, Bell \& Westoby 1986), as well as to the effects of vegetation on food availability (Rozas \& Odum 1988), larval settlement (Bell et al. 1987, Eckman 1987), and predator-prey interactions (Summerson \& Peterson 1984, Leber 1985, Main 1987).

\footnotetext{
- Contribution no. 802 from the Marine Sciences Research Center

- Addressee for reprint requests
}

The physical structure of seagrass can reduce the foraging efficiency of predators which actively pursue prey (Heck \& Orth 1980). This has been clearly demonstrated in cases involving infaunal bivalve prey species, where the seagrass root-rhizome mat impedes penetration of the sediment by predators in pursuit of burrowing prey (Blundon \& Kennedy 1982, Peterson 1982). Above-ground plant structure also interferes with predation on a number of epifaunal prey species (Nelson 1979, Coen et al. 1981, Heck \& Thoman 1981, Stoner 1982, Wilson et al. 1987). Most of these studies have focused on highly motile epifaunal prey, such as amphipods and shrimp, fed on primarily by swimming predators which can access the upper seagrass canopy. However, the existence of a vertical spatial refuge has also been demonstrated in salt marsh systems for the intertidal marsh periwinkle Littorina irrorata, which 
climbs shoots of salt marsh cordgrass Spartina alterniflora during high tide (Hamilton 1976). Studies using field tethering (Warren 1985) and caging techniques (Vaughn \& Fisher 1988) have shown that the snail's vertical climbing behavior significantly reduces predation by blue crabs Callinectes sapidus and conchs Melongena corona. Vertical refuge from benthic predators has not been previously demonstrated for epifauna in seagrass habitats, which are subtidal and have more flexible aboveground plant structures than do salt marshes.

The bay scallop Argopecten irradians is a commercially exploited epifaunal species living in seagrass beds, whose post-settlement abundance is largely controlled by benthic predators such as various crab species, starfish, oyster drills, and whelks (Morgan et al. 1980, Stewart et al. 1981, Tettelbach 1986, Peterson et al. 1989). The bay scallops' early life history includes an initial free-swimming larval stage followed by settlement onto elevated substrates, primarily eelgrass (Zostera marina) blades, to which they attach by means of byssal threads. Scallops, 150 to $190 \mu \mathrm{m}$ in shell height at settlement (Eckman 1987), may remain attached throughout the first few months after settlement, when they experience rapid growth [ca $10 \mathrm{~mm}$ $\mathrm{mo}^{-1}$ (Tettelbach 1986)]. This stage is followed by permanent relocation to the bottom, where scallops live unattached, generally, but not exclusively, within eelgrass beds (Thayer \& Stuart 1974). Spawning of the northern subspecies Argopecten irradians irradians in Long Island (USA) waters occurs primarily in early June (Bricelj et al. 1987) and the peak of larval settlement takes place in early July (Eckman 1987). The period of settlement and attachment thus coincides with the annual peak in eelgrass biomass at this latitude (Adamson 1982).

Attachment is reversible and dynamic; scallops can detach and reattach if disturbed or dislodged (Belding 1910, Eckman 1987). They presumably do so repeatedly during the attachment stage, since eelgrass regularly sheds senescent blades as new ones are formed, with a turnover time of only 6 to $8 \mathrm{~d}$ during the summer months when scallops set (Eckman 1987).

Although the association between bay scallops and eelgrass has long been recognized (Belding 1910, Gutsell 1930), its value as a refuge from predation during the scallops' early life history is poorly understood. Predation is generally recognized as a dominant factor in controlling population abundance of bivalves, especially at the juvenile stage, prior to attainment of a partial size refuge from most predators (Flagg \& Malouf 1983, Eggleston 1990, Peterson 1990). Scallops are particularly vulnerable to predation due to their thin shells, epifaunal habit, and inability to maintain prolonged valve closure. High predatory mortality has been reported in stock-enhancement efforts in which hatchery-reared juvenile bay scallops were released onto unvegetated bottom (Morgan et al. 1980; P. Wenczel, Long Island Green Seal Committee, pers. comm.). Recent recruitment failure of bay scallop populations due to unusual phytoplankton blooms (Cosper et al. 1987, Summerson \& Peterson 1990) have stimulated such stock enhancement efforts. Optimization of reseeding attempts, however, requires improved understanding of this species' habitat requirements for post-settlement survivorship.

The main objectives of this study were (1) to examine the relationship between size of bay scallops and their rate and height of attachment, and (2) to determine the effect of attachment height and density of eelgrass on the scallops' susceptibility to benthic predation. Predation experiments were conducted in both the field and laboratory. Attachment behavior was studied in the laboratory; a subsequent paper (García-Esquivel \& Bricelj unpubl.) will report the size-specific vertical distribution of natural scallop set in the field.

\section{METHODS}

Scallop attachment behavior. The study of juvenile bay scallop attachment behavior was conducted in the laboratory using artificial eelgrass shoot mimics, woven into a plastic VEXAR mesh which was buried under ca $5 \mathrm{~cm}$ of clean sand. Mimics were constructed of buoyant, green, polypropylene ribbon (Synthetic Fibers, Inc., Newton, Pennsylvania) $0.5 \mathrm{~cm}$ in width. Each shoot was made up of 4 approximately equal-length blades. Mimics uniformly covered the entire area of a plexiglass experimental tank (basal area $=31.5 \times 78.5$ $\mathrm{cm}$ ) at either low or high shoot density $(400$ and 800 shoots $\mathrm{m}^{-2}$ respectively). These densities lie within the range of natural eelgrass densities observed in Long Island embayments [e.g. 200 to 1100 shoots $\mathrm{m}^{-2}$ (Eckman 1987)]. The canopy height (vertical distance from the sediment surface to the top of the 'vegetation') was equal to the water depth in the tank $(23 \mathrm{~cm})$. Typical canopy heights of natural eelgrass in Long Island waters range from $24 \mathrm{~cm}$ (Northwest Harbor) to $50 \mathrm{~cm}$ (eastern Hallock Bay) (García-Esquivel \& Bricelj unpubl.).

Eelgrass mimics were used rather than transplanted natural eelgrass in order to create replicates of identical plant density, structure, and condition. Similar mimics have been successfully used in previous studies (Heck \& Thoman 1981, Blundon \& Kennedy 1982, Virnstein \& Curran 1986, Ryer 1988). Argopecten irradians larvae have been shown to readily settle on a variety of artificial substrates, including polypropylene, and settlement appears to be controlled primarily by availabil- 
ity of surface area (Eckman 1987, Ambrose \& Lin in press). It was therefore assumed that chemical or textural differences between mimics and natural eelgrass would have little effect on scallop attachment behavior.

Experimental tanks contained filtered (1 to $5 \mu \mathrm{m}$ ) seawater maintained at 19 to $23^{\circ} \mathrm{C}$ and 26 to $28 \mathrm{ppt}$ salinity and recirculated through a biological filter These temperature and salinity ranges are representative of Long Island waters at the time that scallops set (Hickey 1977). Fluorescent lighting was provided with a light/dark cycle approximating the natural summer photoperiod.

Juvenile scallops, obtained from local hatcheries, were kept in a temperature-controlled flow-through system at the Flax Pond Marine Laboratory, Old Field, New York, prior to experiments. The natural incoming food supply was supplemented by drip-feeding with cultured Thalassiosira weissflogii.

Experiments consisted of replicated attachment trials ( $\mathrm{n}=3$ to 8 ) lasting $24 \mathrm{~h}$, in which a known number of scallops averaging ca $6,10,14$ to 16 , or 20 to $21 \mathrm{~mm}$ in shell height in each trial were dispersed evenly on the sand within artificial eelgrass at either low or high shoot density. The number of scallops used per trial was $150,100,50$, and 25 (i.e. 600,400, 200, and 100 scallops $\mathrm{m}^{-2}$ ) for the $6,10,15$, and $20 \mathrm{~mm}$ size classes respectively. Densities of 6 and $10 \mathrm{~mm}$ scallops are within the range of densities observed in the field by Eckman (1987) for scallops of this size. Stocking densities between 200 and 1200 scallops $\mathrm{m}^{-2}$ (mean shell height $=10 \mathrm{~mm}$ ) do not affect percent and rate of attachment or height attained (García-Esquivel \& Bricelj unpubl.). Shell height (greatest distance from the umbo to the ventral margin) of a subsample of 10 to 50 scallops from each attachment trial was determined using digital calipers accurate to $0.01 \mathrm{~mm}$. The coefficient of variation in shell height averaged $6.3 \% \pm 0.46$ (SE, $\mathrm{n}=37$ trials) and did not exceed $11.3 \%$ in any given trial. No algal food was supplied to scallops during the $24 \mathrm{~h}$ experiments. A single trial with $10 \mathrm{~mm}$ scallops in high shoot density in which scallops were drip-fed cultured Thalassiosira weissflogii indicated that attachment success was not influenced by the presence or absence of food over the short term [ $t$-test for the difference between the single experiment with food and the mean of the rest of the trials with $10 \mathrm{~mm}$ scallops in high shoot density, $\mathrm{p}>0.05$ for total percent attachment and percentage attachment in the upper canopy (see below)]. Position of scallops (bottom, upper or lower half of canopy or walls) was visually determined, generally every 15 to $30 \mathrm{~min}$ for the first $4 \mathrm{~h}$ of the trial, and again at $24 \mathrm{~h}$.

Percent attachment [(number of scallops attached/ total) $\times 100$ ] at 1,4 , and 24 h was arcsine-transformed to correct for deviations from normality (Sokal \& Rohlf
1981), and analyzed by 2-way ANOVA with replication. In addition, percent attachment in the upper half of the artificial eelgrass canopy (out of the total number of scallops attached to shoot mimics), at $24 \mathrm{~h}$, was similarly analyzed. This parameter served as a relative measure of height-above-bottom attained.

Predation study. Experiments to test the effect of vertical attachment on susceptibility to benthic predation were conducted by tethering scallops to natural eelgrass at selected heights in the field and laboratory. Tethered scallops were used rather than free-ranging individuals because tethering allows precise experimental control of attachment height, and prevents the confounding effect of scallop migration in the field. Results of previous laboratory experiments to test the effect of vertical attachment using free-ranging scallops in artificial eelgrass were confounded by variability in percent and height of attachment by scallops between replicate trials (Pohle 1990). Although tethering prevents prey escape, it provides a relative measure of predation intensity, and previous experiments showed that scallops which are firmly attached to artificial eelgrass generally remain in place when blades are disturbed by predators (Pohle 1990).

Field experiment. The field experiment was conducted in Lake Montauk, Long Island, New York $\left(41^{\circ}\right.$ $04^{\prime} \mathrm{N}, 71^{\circ} 55^{\prime} \mathrm{W}$; Fig. 1), between 30 August and 21

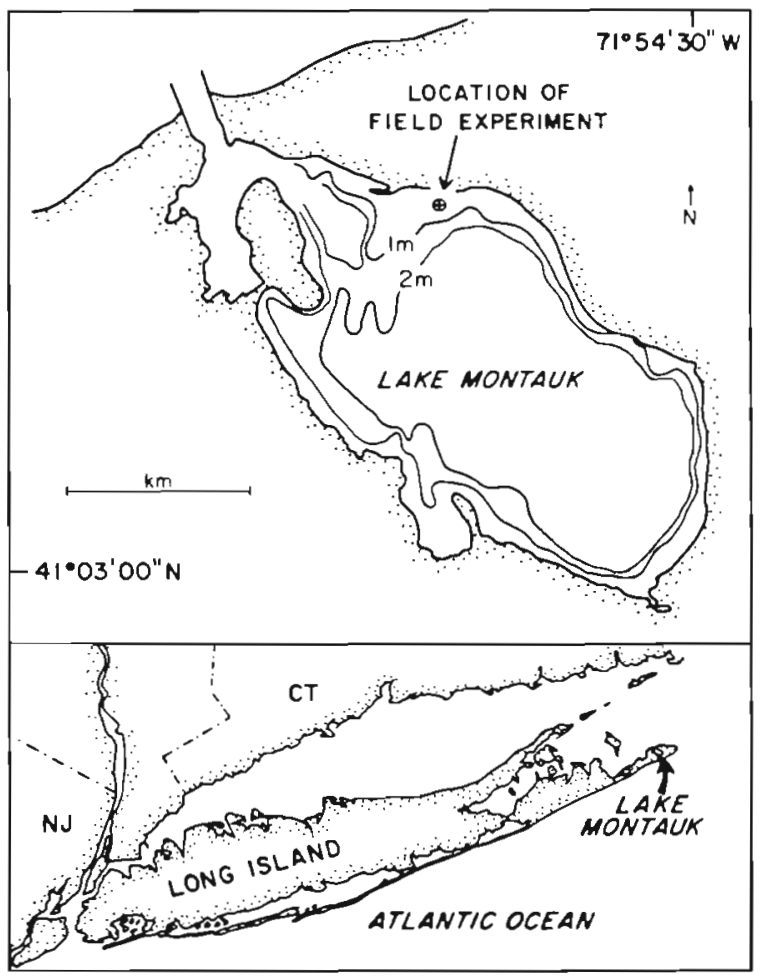

Fig. 1. Lake Montauk, Long Island, New York (USA), showing location of the field tethering experiment 
September 1989. The northeast margin of this bay provided an extensive Zostera marina bed with variable shoot density and a gentle depth gradient. Lake Montauk supported a productive bay scallop fishery prior to the occurrence of 'brown tide' algal blooms in 1985 and 1986 (Hickey 1977). Water temperature during the experiment ranged between 20 and $25^{\circ} \mathrm{C}$, and salinity was 29 ppt.

Scallops were tethered to natural eelgrass at 2 heights within a total of 3 plots in each of 2 eelgrass densities via SCUBA. Plots were $1 \times 2 \mathrm{~m}$, with the perimeters marked by $3 / 16$ in. $(4.8 \mathrm{~mm})$ galvanized chain held down by metal garden stakes (Fig. 2). Due to time constraints in preparing each tethered plot, only 1 pair of plots, a low-and a high-density treatment, was prepared on each of 3 days: 30 August, 3 September, and 9 September. Plots were situated at similar water depth [ca $1.5 \mathrm{~m}$ (tidal average); tidal range $=0.58 \mathrm{~m}$ ], and were widely dispersed ( $>5 \mathrm{~m}$ between plots). Eelgrass densities were estimated visually at the time of plot preparation and quantified at the end of the experiment. Five $12 \mathrm{~cm}$ diameter cores were collected in each experimental plot. For each core the number of shoots was counted and the length of all whole shoots was measured. All above-ground biomass was cleaned with freshwater and dried at $85^{\circ} \mathrm{C}$ to constant weight. High-density plots were located in areas of continuous eelgrass coverage. Low density plots, however, consisted of patches of moderately dense eelgrass in otherwise sparse areas, since it was difficult to find a sufficient number of robust plants suitable for tethering within areas that were uniformly sparse. Surface and subsurface buoys marking the plots were located about $1 \mathrm{~m}$ away to reduce predator attraction and human disturbance (Fig. 2).
Tethers were made from plastic Secur-a-tach ${ }^{\mathrm{R}}$ Fas teners $[3$ in. $(76 \mathrm{~mm}$ ); Dennison Manufacturing Company, Framingham, Massachusetts]. A thickened section of the fastener was cut in half, leaving a flat disk to which a scallop could be glued at one end, and a pointed tip which could be inserted into a plant shoot at the other (Fig. 2 upper left inset). Tethers were applied to air-dried juvenile scallops ( 10 to $15 \mathrm{~mm}$ ) with Krazy Glue ${ }^{\mathrm{R}}$ in the laboratory at least $1 \mathrm{~d}$ prior to placement in the field. Scallops were then transported live to the study site in styrofoam containers filled with wet newspaper. No mortality occurred during transport. Scallops were tethered to shoots at the desired elevation by piercing a small hole with sharp forceps and inserting the pointed tip of the tether. Thickenings in the tethers made them very difficult to dislodge. Two scallops were placed on each shoot, one as close to the base of the stem as possible $(<5 \mathrm{~cm}$ high) and the other at 20 to $35 \mathrm{~cm}$ above bottom. In the field, scallops of this size are found attached to eelgrass at heights ranging anywhere from 2 to $48 \mathrm{~cm}$ (García-Esquivel \& Bricelj unpubl.). A total of 100 scallops were tethered in each plot, except for one low- and one high-density plot in which 58 and 50 scallops respectively were tethered. Shoots on which scallops were placed were marked with a Secur-a-tach ${ }^{R}$ Fastener at the tip of a blade to facilitate relocation (Fig. 2).

To control for possible loss of scallops due to factors other than predation (e.g. shedding of blades or removal of tethers by animals attracted to the plastic tether), a $1 \times 1 \mathrm{~m}$ plot was set up on 2 separate days in an area of intermediate eelgrass density in which tethers without scallops where inserted in plants as described above. Shoots were marked as in the plots with scallops. To control for detachment of scallops

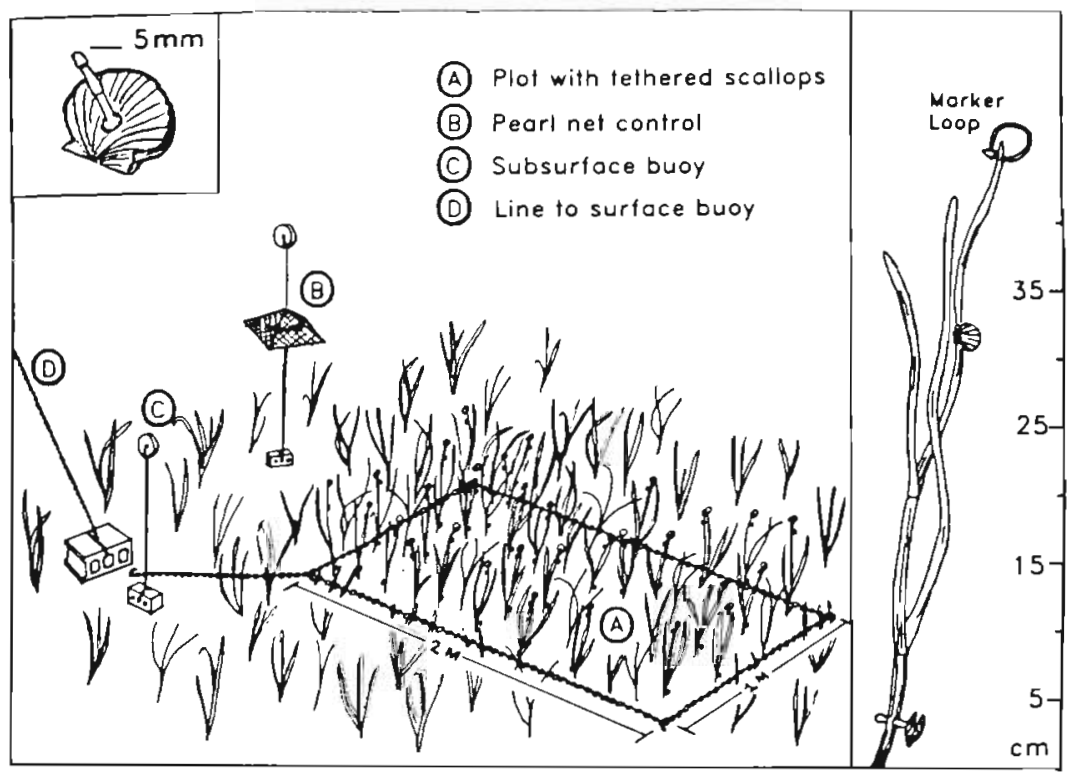

Fig. 2. Schematic drawing of a typical treatment plot used in the field tethering experiment, showing approximate placement of the pearl net control (B) relative to the plot, and approximate vertical height of tethered scallops (Argopecten irradians) on an eelgrass shoot (inset at right). Also shown is a scallop with a plastic tether glued to its shell (inset in upper left corner) 
from tethers, 16 to 20 scallops were tethered to polypropylene ribbon which was hung inside pearl nets ( $7 \mathrm{~mm}$ mesh) suspended at mid-depth so that predators could not reach them. Two pearl nets, suspended from subsurface, anchored buoys (Fig. 2), were deployed, one in close proximity to each treatment plot, at the time plots were prepared.

All plots and pearl net controls were checked 2 and 4 $\mathrm{d}$ after initial deployment. In treatment plots data were recorded as $(A)$ tether with live scallop, $(B)$ tether with broken shell or empty intact valves attached, $(C)$ tether with no shell remains, or $(D)$ both tether and scallop missing. After each shoot was checked, part of the marker was cut off with scissors to verify that the data had been recorded from that particular shoot. Percent survival was calculated as $[A /(A+B+C+D)] \times 100$. Since pairs of treatment plots were prepared on 3 separate days, percent survival of scallops at 2 and $4 \mathrm{~d}$ after tethering was analyzed by 3 -way ANOVA without replication, with tethering height and shoot density as fixed treatments and tethering days as a random factor.

To identify potential predator species responsible for scallop mortality in the field, a predator survey was conducted after the last set of plots was dismantled. Divers swam along fourteen $20 \mathrm{~m}$ long random transects in the experimental area, searching the grass and substrate within a $1 \mathrm{~m}$ width. Divers also searched for burrowed animals (e.g. spider crabs) and animals under rocks and shells (e.g. mud crabs). All potential macrofaunal predators were counted and identified to species when possible.

Laboratory experiments. In the field experiment scallop mortality could not be unequivocally attributed to particular predator species. Therefore, further examination of the relationship between scallop vertical position and mortality caused by individual predators was undertaken in the laboratory through tethering experiments with 3 predator species found to be common in the study area: green crabs Carcinus maenas, spider crabs Libinia dubia, and mud crabs Dyspanopeus (= Neopanope) sayi. D. sayi was the most abundant predator in the field survey and was the only crab species observed climbing eelgrass in the field.

Experiments were conducted in a flow-through system with seawater maintained at constant temperature $\left(20^{\circ} \mathrm{C}\right.$; salinity $\left.=28 \mathrm{ppt}\right)$ at the Flax Pond Marine Laboratory. Natural eelgrass, collected from local embayments, was transplanted into plexiglass tanks (basal area $=31.5 \times 78.5 \mathrm{~cm}$; water depth $=46 \mathrm{~cm}$ ). Fifty-six shoots $\left(224 \mathrm{~m}^{-2}\right)$ were tied to VEXAR mesh with metal twist ties and the mesh was buried under 5 $\mathrm{cm}$ of clean sand. Thirty-five scallops were tethered at the base of shoots ( $<5 \mathrm{~cm}$ above bottom) and 35 were tethered to blades ( 20 to $35 \mathrm{~cm}$ above bottom) as in the field. The effect of eelgrass density was not tested in the laboratory experiments.

Crabs were collected at the field site. Four green crabs [53 to $67 \mathrm{~mm}$ in carapace width (CW)] and 4 spider crabs (42 to $53 \mathrm{~mm} \mathrm{CW}$ ) were tested individually. Mud crabs were tested in groups of 5 because of their relatively small size, high densities in the field, and gregarious habit. Five groups of mud crabs were used, ranging in size between 19 and $26 \mathrm{~mm} \mathrm{CW}$ (mean $\mathrm{CW}$ per group $=21$ to $22 \mathrm{~mm}$ ).

Crabs were starved for 2 to $3 \mathrm{~d}$ prior to experiments and then allowed to prey on scallops for $48 \mathrm{~h}$. Percent survival (calculated as above) at 24 and $48 \mathrm{~h}$ was analyzed by 2 -way ANOVA without replication, with scallop height as a fixed treatment and individual crabs or crab groups as a random factor. As in the field, records were kept of tethers with broken shell, tethers with no shell, or loss of tethers from the plants.

\section{RESULTS}

\section{Scallop attachment behavior}

Scallops generally became active immediately upon release into experimental tanks. Attachment to vertical substrates (i.e. eelgrass shoot mimics and tank walls) proceeded by 2 methods. The most common method was to extend the foot, adhere it to a vertical surface, and then pull the body up. Alternatively, scallops swam to the surface of the water, extended the foot, and then 'caught' onto a blade mimic while passively sinking. The letter method was commonly attempted only by the smaller size classes $(<15 \mathrm{~mm})$ and was rarely successful in achieving attachment. Following attachment, scallops generally proceeded to climb vertically. They did so by a 2 -step procedure, first extending the foot up along the vertical surface and adhering it at the distal end, then contracting the foot, thereby pulling the body up to a higher position in a jerking motion [for a detailed description of this crawling behavior see Belding (1910)].

The number of attached scallops increased asymptotically over time for all size classes (Fig. 3), but the magnitude and the rate of increase in percent attachment varied inversely with scallop size in both shoot densities. The difference among size classes in percent attachment was highly significant at all time points analyzed (2-way ANOVA, p $<0.001$ ), with no significant difference between shoot densities and no significant interaction ( $p>0.05$ ). A posteriori Bonferroni comparisons between 6 and $10 \mathrm{~mm}$ size classes were highly significant $(p<0.001)$ at 1 and $4 h$, and significant $(p<0.05)$ at $24 \mathrm{~h}$. Comparisons between 10 and $15 \mathrm{~mm}$ 


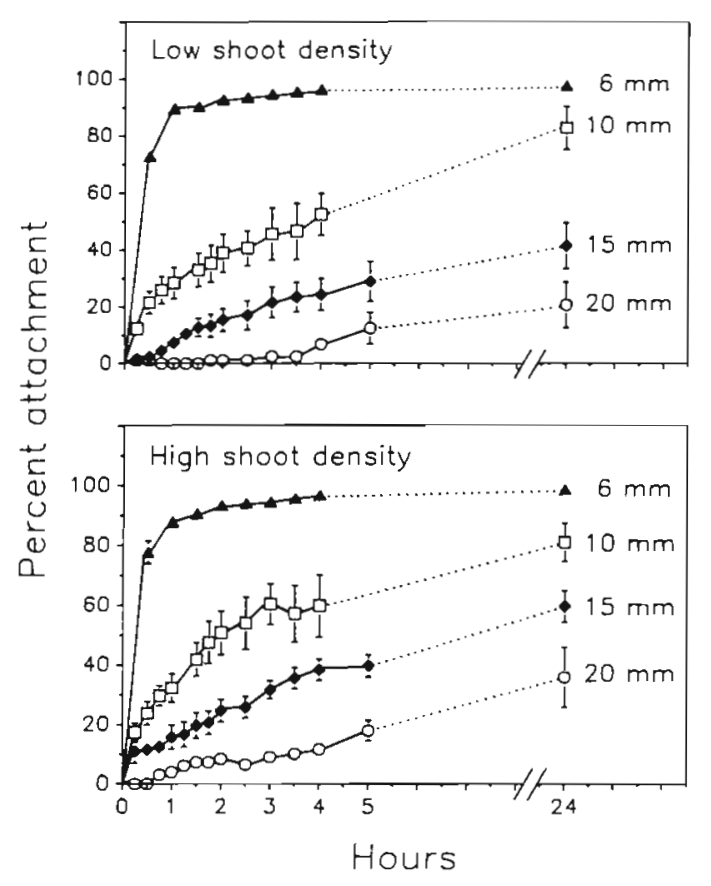

Fig. 3. Argopecten irradians. Mean percent attachment of 4 size classes of juvenile bay scallops $(6,10,15$, and $20 \mathrm{~mm}$ mean shell height $)$ in low- $\left(400\right.$ shoots $\left.\mathrm{m}^{-2}\right)$ and high- $(800$ shoots $\mathrm{m}^{-2}$ ) density artificial eelgrass mimics over $24 \mathrm{~h}$ (scallops attached to tank walls excluded from the sample). Error bars represent the standard error (SE) for 3 to 8 replicate trials

size classes were highly significant $(p<0.01)$ at all 3 time points tested. However, no comparisons between 15 and $20 \mathrm{~mm}$ size classes were significant.

An increasing tendency to attach to tank walls with increasing scallop size and decreasing shoot density was also observed [2-way ANOVA of percent attachment on tank walls (out of the total number of attached scallops), $p<0.001$ for both size and density effects at $24 \mathrm{~h}$, no significant interaction; Fig. 4]. A posteriori Bonferroni comparisons for this effect were not significant between 6 and $10 \mathrm{~mm}$, or between 10 and $15 \mathrm{~mm}$ size classes, but were highly significant $(p<0.01)$ between 15 and $20 \mathrm{~mm}$ scallops. To correct for this 'wall effect', attachment data (Fig. 3) were recalculated by excluding scallops attached to walls (i.e. percent attachment $=$ [scallops on mimics / (total scallops scallops on walls)] $\times 100)$. For the largest $(20 \mathrm{~mm})$ size class the percent attachment values obtained with this correction were substantially lower than the uncorrected values (e.g. $20.7 \%$ vs $62.0 \%$ attachment, respectively, at $24 \mathrm{~h}$ in low-density mimics). This correction, however, had only a negligible effect on percent attachment values obtained for the smaller ( 6 and $10 \mathrm{~mm}$ ) size classes. Two-way ANOVA of percent attachment excluding scallops attached to walls (i.e. corrected values) gave results similar to those obtained for uncorrected data, but also revealed a significant difference between 15 and $20 \mathrm{~mm}$ scallops (Table 1). Exclusion of scallops attached to walls thus provided evidence of a continuous trend of decreasing attachment success with increasing scallop size within the complete range tested.

The height attained varied considerably among size classes and among individuals within a size class. Small $(6 \mathrm{~mm})$ scallops showed the greatest upward movement (Fig. 4). More than $50 \%$ of the $6 \mathrm{~mm}$ scallops attached to mimics reached the upper half of the canopy $(>11.5 \mathrm{~cm})$ within $24 \mathrm{~h}$. Large $(20 \mathrm{~mm})$ scallops were never found in the upper half of the canopy, but generally remained attached near the base of the shoot mimics or walls. Differences in percent attachment in the upper canopy (out of the total number attached to shoot mimics) at $24 \mathrm{~h}$ were highly significant (2-way ANOVA, $p<0.001$ ) among size classes, with no significant difference between shoot densities, and no significant interaction. A posteriori Bonferroni comparisons between the 6 and $10 \mathrm{~mm}$ and the 15 and $20 \mathrm{~mm}$ size classes were significant ( $p<0.05$ and $p<0.01$, respectively), but there was no significant difference between 10 and $15 \mathrm{~mm}$ scallops.

The time required for scallops to reach the upper

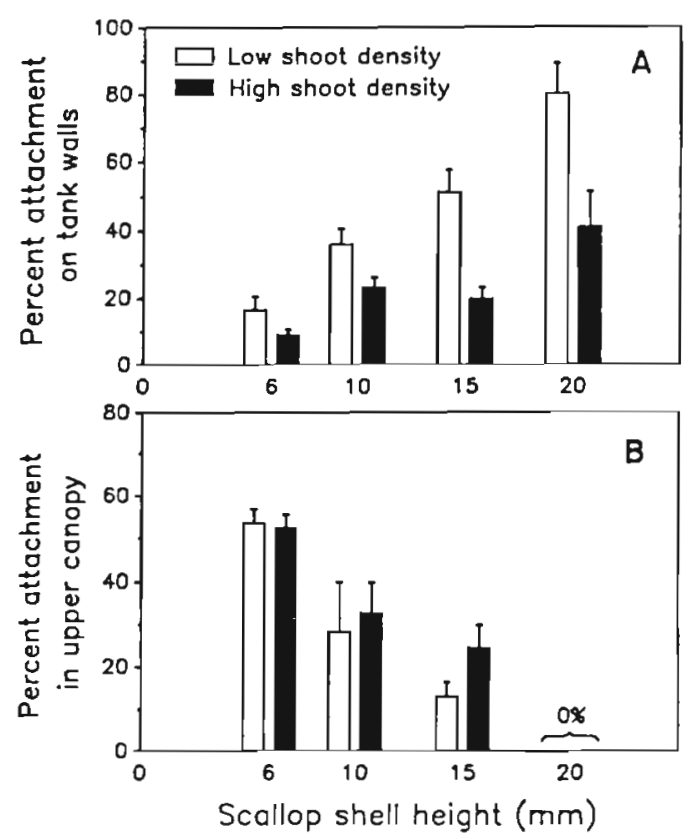

Fig. 4. Argopecten irradians. Mean percent attachment (A) on tank walls (out of total number of attached scallops), and ( $B$ ) in the upper half of the artificial eelgrass canopy lout of total number of scallops attached to mimics), at $24 \mathrm{~h}$ for 4 size classes of juvenile bay scallops in low- $\left(400\right.$ shoots $\left.\mathrm{m}^{-2}\right)$ and high- $\left(800\right.$ shoots $\left.\mathrm{m}^{-2}\right)$ density artificial eelgrass. Error bars as in Fig. 3 
Table 1. Argopecten irradians. Results of 2-way ANOVAs with replication ( $\mathrm{n}=3$ to 8 trials per size class in each shoot density), and Bonferroni comparisons between size classes, for percent attachment of juvenile bay scallops at 1, 4, and $24 \mathrm{~h}$ (scallops attached to tank walls excluded from the sample). Four scallop size classes $(6,10,15$, and $20 \mathrm{~mm}$ mean shell height) and 2 shoot densities of artificial eelgrass ( 400 and 800 shoots $\mathrm{m}^{-2}$ ) were used

\begin{tabular}{|c|c|c|c|c|c|c|c|}
\hline \multirow{2}{*}{$\begin{array}{l}\text { Source of } \\
\text { variation }\end{array}$} & \multirow{2}{*}{$\mathrm{df}$} & \multicolumn{2}{|c|}{$1 \mathrm{~h}$} & \multicolumn{2}{|c|}{$4 \mathrm{~h}$} & \multicolumn{2}{|c|}{$24 \mathrm{~h}$} \\
\hline & & MS & $F$ & MS & $F$ & MS & $F$ \\
\hline Shoot density & 1 & 168.90 & $3.21 \mathrm{~ns}$ & 241.45 & 2.98 ns & 283.73 & $2.07 \mathrm{~ns}$ \\
\hline Scallop size & 3 & 5694.38 & $108.26^{\cdots} \cdot$ & 5044.94 & $62.30^{\cdots} \cdot$ & 3973.88 & $28.94^{\cdots} \cdots$ \\
\hline Interaction & 3 & 48.79 & $0.93 \mathrm{~ns}$ & 37.22 & $0.46 \mathrm{~ns}$ & 118.85 & $0.87 \mathrm{~ns}$ \\
\hline Error & 29 & 52.60 & & 80.98 & & 137.31 & \\
\hline $6 \mathrm{vs} 10 \mathrm{~mm}$ & 1 & 4795.11 & $91.16^{\cdots} \cdot$ & 3205.48 & $39.59 \cdots$ & 1021.20 & $7.44^{\circ}$ \\
\hline 10 vs $15 \mathrm{~mm}$ & 1 & 1200.34 & $22.82^{\cdots}$ & 1290.55 & $15.94^{\circ}$ & 2251.86 & $16.40^{\circ}$ \\
\hline 15 vs $20 \mathrm{~mm}$ & 1 & 998.59 & $18.99^{\circ} \cdot$ & 1465.29 & $18.10^{\circ} \cdot$ & 1180.31 & $8.60^{\circ}$ \\
\hline Error & 29 & 52.60 & & 80.98 & & 137.31 & \\
\hline
\end{tabular}

canopy also varied with scallop size. Within the first $0.5 \mathrm{~h}, 18 \%$ of the $6 \mathrm{~mm}$ scallops attached to shoot mimics were located in the upper canopy, whereas $10 \mathrm{~mm}$ scallops were first found in the upper canopy at $1.3 \mathrm{~h}$, and $15 \mathrm{~mm}$ scallops at $>2.6 \mathrm{~h}$. Attachment during climbing seemed to be weak, since scallops sometimes fell while contracting the foot. Fallen scallops often reattached immediately and reinitiated climbing.

\section{Predation study: field experiment}

The field tethering experiment revealed a dramatic enhancement of scallop survival in the upper canopy (20 to $35 \mathrm{~cm}$ above bottom) relative to the base of the shoots ( $<5 \mathrm{~cm}$ above bottom), which was significant at $2 \mathrm{~d}$, and highly significant at $4 \mathrm{~d}$ after tethering (Fig. 5 , Table 2). Survival also increased significantly with eelgrass density at both 2 and $4 \mathrm{~d}$, with no significant

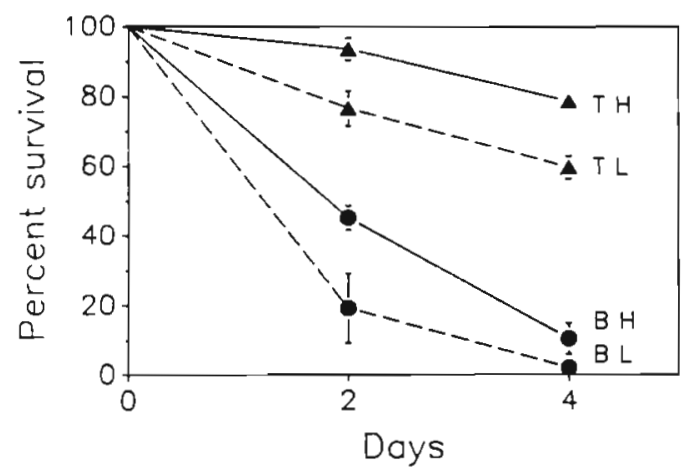

Fig. 5. Argopecten irradians. Mean percent survival (over 4 d) of juvenile bay scallops tethered to natural eelgrass in Lake Montauk, Long Island, New York, USA, at the base of the shoots $(B$, bottom) and in the upper canopy $(T$, top), $<5 \mathrm{~cm}$ and 20 to $35 \mathrm{~cm}$ above bottom respectively, in plots of low- (L) and high- $(\mathrm{H})$ density eelgrass. Error bars represent the standard error for 3 plots interaction between tethering height and eelgrass density at either sampling time (Table 2).

Retention of scallops on tethers in pearl nets, and retention in the plants of tethers without scallops over the experimental period, were very high (Table 3 ). More than $98 \%$ of scallops in pearl nets remained bound to tethers over $4 \mathrm{~d}$. Thus loss of scallops from tethers in the absence of predation was negligible over the course of the experiment. Retention of tethers without scallops was $>90 \%$ in the upper canopy and at the base of the shoots over $4 \mathrm{~d}$ (Table 3 ). However, retention in the upper canopy (90 to $96 \%$ ) was marginally less than at the bottom (95 to $99 \%$ ).

In treatment plots, tethers with no shell remains were found almost as frequently as tethers with broken shell or empty intact valves attached (Table 4). Both may be considered evidence of predatory mortality, since loss of scallops from tethers in pearl nets, which were inaccessible to predators, was negligible. Also, shell debris was often found around the base of shoots where no shell was found on a tether.

Cases in which both tether and scallop were missing made up a larger percentage of scallop loss in the upper canopy (33 to $53 \%$ ) than on the bottom $(4 \%$ ) (Table 4). However, since few scallops were lost from the upper canopy, this large percentage actually represents only a small number of scallops $(<5)$. Since a marginally greater loss of tethers was also found in the upper canopy in plots where tethers without scallops were placed (see Table 3 ), it is possible that this loss may not be due to predation. Rather, it may be due to natural shedding of blades on which scallops were tethered, or frictional drag of currents on tethered scallops in the upper canopy, causing increased blade loss. If some small portion of scallop loss from the upper canopy was indeed caused by factors other than benthic predation, the highly significant effect of 
Table 2. Argopecten irradians. Results of 3-way ANOVAs without replication for percent survival of juvenile bay scaliops 2 and $4 \mathrm{~d}$ after tethering. Scallops were tethered to natural eelgrass at 2 heights $(<5 \mathrm{~cm}$ and 20 to $35 \mathrm{~cm})$ above bottom in areas of lowand high-density eelgrass on each of 3 days in Lake Montauk, Long Island, New York. USA

\begin{tabular}{|c|c|c|c|c|c|c|}
\hline \multirow{3}{*}{$\begin{array}{l}\text { Source of } \\
\text { variation }\end{array}$} & \multicolumn{6}{|c|}{ Days after tethering } \\
\hline & & & & & & \\
\hline & $\mathrm{df}$ & MS & $F$ & df & MS & $F$ \\
\hline Tethering height & 1 & 4060.76 & $25.48^{\circ}$ & 1 & 5906.70 & $348.37^{\cdots}$ \\
\hline Eelgrass density & 1 & 933.60 & $78.09^{\circ}$ & 1 & 392.43 & $42.49^{\circ}$ \\
\hline Tethering days & 2 & 96.30 & & 2 & 15.51 & \\
\hline Height $\times$ Density & 1 & 2.47 & $0.02 \mathrm{~ns}$ & 1 & 0.85 & $0.01 \mathrm{~ns}$ \\
\hline Height $\times$ Days & 2 & 159.38 & & 2 & 16.96 & \\
\hline Density $\times$ Days & 2 & 11.95 & & 2 & 9.23 & \\
\hline Remainder & 2 & 105.73 & & 2 & 90.33 & \\
\hline
\end{tabular}

tethering height observed in this study may in fact be conservative.

A potential confounding factor in this experiment was loss of entire shoots from plots (i.e. no marker, tethers, or scallops recovered). Over $4 \mathrm{~d}$ this loss amounted to $<5$ shoots per plot, except for 1 lowdensity plot in which 10 out of 50 shoots were missing. Since some whole shoot loss was also found in plots where tethers without scallops were placed, it was probably due to tidal or wind-induced scouring and advection of plant material, not the activity of predators. Scallop survival estimates were therefore based on the number of remaining shoots, rather than the original number on which scallops were tethered.

Characterization of grass density in the plots (Table 5) showed differences between treatments with respect to shoot density and biomass, but these differences were not statistically significant [single classification ANOVA, $p>0.05$ ( $p=0.055$ for biomass)]. However, lack of significance may be related to the small sample sizes ( 3 per treatment) used in the analysis.

The predator survey showed 5 potential benthic predators of juvenile scallops: mud crabs Dyspanopeus sayi, spider crabs Libinia dubia, green crabs Carcinus maenas, hermit crabs Pagurus longicarpus, and starfish Asterias forbesii. Of these, mud crabs were most abundant. Because of their high density and cryptic behavior, an additional survey of three $5 \times 1 \mathrm{~m}$ transects was conducted to more accurately assess population abundance of this species, revealing a density of $6 \pm 1.4$ (SE) crabs $\mathrm{m}^{-2}$. Many individuals, however, were probably too small to feed on the scallops used in this experiment. All other species occurred at densities of $<2$ ind $20 \mathrm{~m}^{-2}$. Hermit crabs probably did not prey on tethered scallops; Tettelbach (1986) showed in laboratory experments that $P$. longicarpus representative of the largest individuals of this species found in the field (22 $\mathrm{mm}$ in gastropod shell diameter) do not feed on bay scallops $\geq 6 \mathrm{~mm}$. Numerous juvenile winter flounder Pseudopleuronectes americanus were also observed, but were probably too small to feed on tethered scallops. According to Keats (1990), winter flounder up to $50 \mathrm{~cm}$ in length cannot feed on prey items $>16 \mathrm{~mm}$ in smallest cross-sectional diameter. Other fish species encountered over the course of the study, but not observed in the predator survey, included toadfish Opsanus tau and juvenile tautogs Tautoga onitis. Although these presumably could have fed on tethered scallops, their presence was rare. Only starfish and mud crabs were actually observed feeding on scallops in the field. In 1 plot, 14 out of 48 scallops tethered at the base of the shoots were apparently consumed by a single starfish, as evidenced by the presence of intact empty valves and an adjacent starfish feeding on a tethered scallop in the plot.

\section{Predation study: laboratory experiments}

Laboratory tethering experiments confirmed results obtained in the field. Scallop survival was significantly greater in the upper canopy than at the base of the

Table 3. Mean \pm (SE) percent retention of tethers in plants for 2 plots in which tethers without scallops Argopecten irradians were placed, 2 and $4 \mathrm{~d}$ after placement at the base of the shoots and in the upper canopy $(<5 \mathrm{~cm}$ and 20 to $35 \mathrm{~cm}$ above bottom, respectively); and mean $\pm(S E)$ percent retention of scallops on tethers in pearl net controls $(n=6)$

\begin{tabular}{|lccc|}
\hline $\begin{array}{l}\text { Days } \\
\text { after } \\
\text { placement }\end{array}$ & $\begin{array}{l}\text { Tethers without scallops } \\
\text { Base of } \\
\text { shoots }\end{array}$ & $\begin{array}{c}\text { Upper } \\
\text { canopy }\end{array}$ & $\begin{array}{c}\text { Pearl net } \\
\text { controls }\end{array}$ \\
\hline 2 & $99.0(1.05)$ & $95.5(2.40)$ & $992(0.83)$ \\
4 & $94.6(5.45)$ & $90.1(1.20)$ & $98.3(1.67)$ \\
\hline
\end{tabular}


Table 4. Argopecten irradians. Breakdown of scallop losses as a percent of total loss (4 $\mathrm{d}$ after tethering to natural eelgrass in Lake Montauk, Long Island, New York, USA) into 3 categories: (1) tether recovered with shell fragments or empty intact valves attached, (2) tether recovered with no shell fragments attached, and (3) neither tether nor scallop recovered (no tether) (see text). Also shown is the total number of scallops lost for comparison of sample sizes used in calculating percentages above. Values are means $\pm(\mathrm{SE})(\mathrm{n}=3)$

\begin{tabular}{|c|c|c|c|c|}
\hline \multirow[t]{3}{*}{ Result } & \multicolumn{4}{|c|}{ Treatment } \\
\hline & \multicolumn{2}{|c|}{ Low grass density } & \multicolumn{2}{|c|}{ High grass density } \\
\hline & Base of shoots & Upper canopy & Base of shoots & Upper canopy \\
\hline Tether with shell & $49.5(11.62)$ & $40.1(9.93)$ & $51.6(8.80)$ & $23.7(13.35)$ \\
\hline Tether without shell & $46.5(9.86)$ & $27.4(2.25)$ & $44.8(7.96)$ & $23.0(6.00)$ \\
\hline No tether & $4.1\{2.37\}$ & $32.6(7.80)$ & $3.5(2.47)$ & $53.3(11.31)$ \\
\hline Total no lost & $37(6.9)$ & $15(1.9)$ & $37(9.1)$ & $8(2.9)$ \\
\hline
\end{tabular}

Table 5. Characterization of plots used in scallop tethering experiment in Lake Montauk, Long Island, New York, USA. Values are means $\pm(\mathrm{SE})$

\begin{tabular}{|lccc|}
\hline Treatment & $\begin{array}{c}\text { Plant length } \\
(\mathrm{cm})\end{array}$ & $\begin{array}{c}\text { Shoot density } \\
\left.\text { (no. shoots } \mathrm{m}^{-2}\right)\end{array}$ & $\begin{array}{c}\text { Biomass } \\
\left(\mathrm{g} \mathrm{dry}_{\mathrm{wt}} \mathrm{m}^{-2}\right)\end{array}$ \\
\hline Low eelgrass density $(\mathrm{n}=3)$ & $35(3.4)$ & $472(77.9)$ & $85.5(16.40)$ \\
High eelgrass density $(\mathrm{n}=3)$ & $47(0.9)$ & $678(106.1)$ & $280.0(69.67)$ \\
Tethers without scallops $(\mathrm{n}=2)$ & $34(3.0)$ & $619(88.0)$ & $106.1(35.40)$ \\
\hline
\end{tabular}

shoots at $24 \mathrm{~h}$ for all 3 predator species tested (Fig. 6, Table 6). At $48 \mathrm{~h}$ this difference was highly significant for spider crabs and mud crabs, and significant for green crabs (Table 6). However, the level of predation on scallops tethered in the upper canopy varied considerably among predator species (Fig, 6). Whereas scallops in the upper canopy experienced an almost absolute refuge from predation by spider crabs and green crabs, mud crabs proved to be relatively adept at foraging in the upper canopy, where they consumed on average $34 \%$ of the scallops tethered. Mud crabs climbed eelgrass by wrapping their legs around the shoots and sometimes hung upside-down from blades while crushing and eating scallops. Usually, however, only 1 or 2 mud crabs from a group of 5 consumed scallops in the upper canopy, and these would remain in the canopy for an extended period, moving from plant to plant. Spider crabs and green crabs were not observed climbing shoots or pulling down blades.

\section{DISCUSSION}

\section{Scallop attachment behavior}

Attachment trials revealed a strong, highly significant inverse relationship between scallop size and attachment performance for 6 to $20 \mathrm{~mm}$ scallops, which was similar in both low and high shoot densities. These results agree with those obtained by Caddy (1972) in a study of size-specific byssal attachment by the deep sea scallop Placopecten magellanicus. Individuals of this species attach to hydroids and bryozoans as juveniles, and may continue to attach to gravel and shell fragments as adults. Caddy observed $75 \%$ attachment of 2 to $5 \mathrm{~mm}$ juveniles onto a glass surface after $30 \mathrm{~min}$. $\mathrm{He}$ also described an inverse relationship between scallop size and both percent attachment and rate of attachment of adult scallops (40 to $130 \mathrm{~mm}$ ).

An examination of the cause of size-specific attachment performance or the effects of varying flow regime on attachment behavior was beyond the scope of this study. The inverse relationship between scallop size and height attained above bottom, reflecting a greater ability of small scallops to climb by crawling, may be related to an ontogenetic decrease in the ratio of foot size to total body size (see Belding 1910).

\section{Predation study}

Results of the predation study unequivocally demonstrated the role of vertical attachment in reducing susceptibility to benthic predation. Both field and laboratory experiments revealed highly significant enhancement of scallop survival in the upper eelgrass canopy, 20 to $35 \mathrm{~cm}$ above bottom, relative to the base of the 

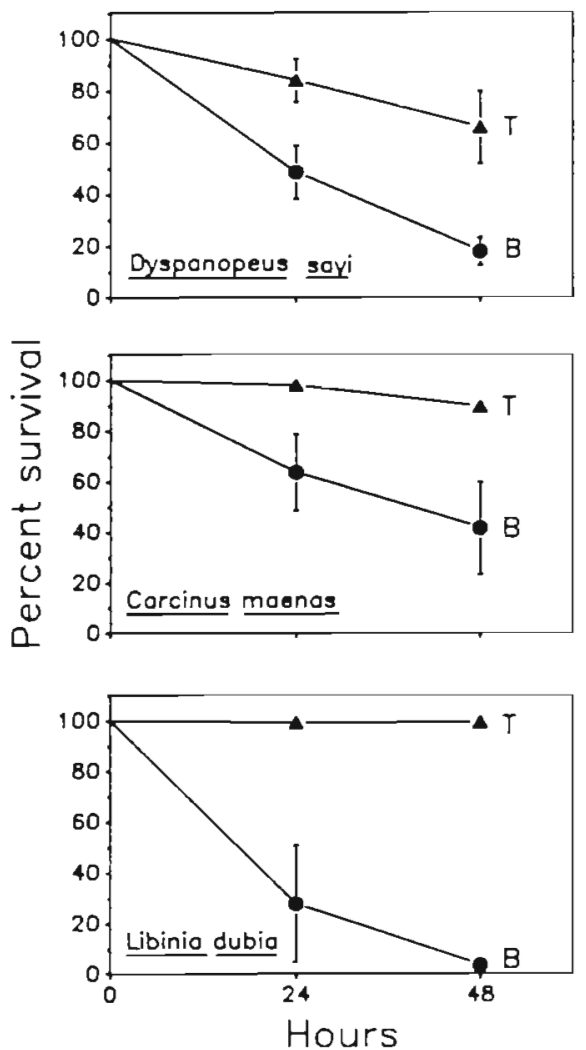

Fig. 6. Argopecten irradians. Mean percent survival (over $48 \mathrm{~h}$ ) of juvenile bay scallops tethered to transplanted natural eelgrass in the laboratory at the base of the shoots ( $\mathrm{B}$, bottom) and in the upper canopy ( $\mathrm{T}$, top), $<5 \mathrm{~cm}$ and 20 to $35 \mathrm{~cm}$ above bottom, respectively, and preyed on by rnud crabs Dyspanopeus sayi, green crabs Carcinus maenas, and spider crabs Libinia dubia. Error bars represent the standard error for

5 groups of mud crabs, 4 green crabs, and 4 spider crabs

shoots. Scallops $<15 \mathrm{~mm}$ in shell height which attach in the upper canopy may thus be at considerably less risk of benthic predatory mortality than those which remain unattached or attach at the base of the shoots. This may result from the upper canopy being beyond reach of many benthic predators, and/or their inability to climb the shoots in search of prey, and/or a general tendency not to do so (e.g. due to the presence of alternative prey on the bottom). A prior study (Main 1987) has also shown a partial refuge from predation in the upper seagrass canopy for Tozeuma carolinense, a caridean shrimp, preyed upon by the pinfish Lagodon rhomboides, which prefers to feed near the base of the blades.

Although there was a highly significant positive effect of height-above-bottom on survival with mud crabs Dyspanopeus sayi as predators, scallops experienced only partial refuge from predation by this species. In laboratory experiments mud crabs readily climbed shoots to forage in the upper canopy, consum- ing $34 \%$ of the scallops tethered there within $48 \mathrm{~h}$. This predation rate is somewhat greater than that observed for scallops tethered in the upper canopy in the field over $2 \mathrm{~d}(23.3 \%$ in low-density eelgrass). Differences in absolute predation rates could result from laboratory confinement effects, the absence of alternative prey and/or differences in predator and eelgrass densities between laboratory and field studies. Since mud crabs were numerically dominant at the field study site, and exist in high densities in other embayments in eastern Long Island where bay scallops occur (Flagg \& Malouf 1983), they may play a major role in reducing abundances of juvenile scallops. Thus the dynamics of mud crab predation on juvenile bay scallops deserves further attention

Results of the predation study also indicated a direct relationship between prey (scallop) survival and eelgrass density, as would be predicted based on a number of previous studies testing the effects of increasing seagrass density on predatory mortality (Nelson 1979, Heck \& Thoman 1981, Stoner 1982). The consistently greater survival of scallops in high-density relative to low-density eelgrass, however, may be related to the characteristics of the areas in which the treatment plots were set up, as well as the density of vegetation within the plots themselves. High density plots were located in areas of generally continuous grass coverage whereas low density plots were placed in areas where Zostera marina showed a sparser, patchier distribution. Since patchiness and eelgrass density may have been confounded in the present study, further investigation in areas offering a greater contrast in eelgrass density will be necessary to improve our understanding of its effects on scallop survival.

Thus the function of the association between juvenile bay scallops and eelgrass may be understood primarily in terms of the spatial refuge value of above-bottom attachment. Further studies at sites characterized by different predator assemblages will be necessary, however, to generalize this conclusion. In addition, the association of scallops with eelgrass may have other possible adaptive roles. Vertical attachment may serve to keep scallops out of unconsolidated sediments during the period when they are most vulnerable to mortality from burial or siltation (Belding 1910, Yamamoto 1960, Castagna 1975). It may also promote scallop growth by placing scallops in a region of high current velocities relative to the bottom, thus providing them with a greater flux of suspended food (Belding 1910, Eckman et al. 1989). Baffling of currents by eelgrass blades may also enhance larval settlement through passive hydrodynamic processes (Eckman 1987).

These results, in combination with those of a prior study (Tettelbach 1986), suggest a novel life history 
Table 6. Argopecten irradians. Results of 2-way ANOVAs without replication for percent survival (after 24 and 48 h) of juvenile bay scallops tethered to transplanted natural eelgrass in the laboratory at 2 heights $(<5 \mathrm{~cm}$ and 20 to $35 \mathrm{~cm})$ above bottom in experiments using 5 groups of mud crabs Dyspanopeus sayi, 4 green crabs Carcinus maenas, and 4 spider crabs Libinia dubia as predators

\begin{tabular}{|c|c|c|c|c|c|}
\hline $\begin{array}{l}\text { Time } \\
\text { (h) }\end{array}$ & Species & Source of variation & $\mathrm{df}$ & MS & $F$ \\
\hline \multirow[t]{9}{*}{24} & D. sayi & Tethering height & 1 & 1570.91 & $8.98^{\circ}$ \\
\hline & & Groups & 4 & 246.33 & \\
\hline & & Remainder & 4 & 174.97 & \\
\hline & C. maenas & Tethering height & 1 & 1576.14 & $10.73^{\circ}$ \\
\hline & & Individuals & 3 & 267.04 & \\
\hline & & Remainder & 3 & 146.94 & \\
\hline & L. dubia & Tethering height & 1 & 7148.15 & $11.82^{\circ}$ \\
\hline & & Individuals & 3 & 695.82 & \\
\hline & & Remainder & 3 & 604.62 & \\
\hline \multirow[t]{9}{*}{48} & D. sayi & Tethering height & 1 & 2860.23 & $23.222^{\circ}$ \\
\hline & & Groups & 4 & 475.30 & \\
\hline & & Remainder & 4 & 123.19 & \\
\hline & C. maenas & Tethering height & 1 & 2526.92 & $14.83^{\circ}$ \\
\hline & & Individuals & 3 & 565.65 & \\
\hline & & Remainder & 3 & 170.41 & \\
\hline & L. dubia & Tethering height & 1 & 12227.74 & $255.70 \cdots$ \\
\hline & & Individuals & 3 & 18.70 & \\
\hline & & Remainder & 3 & 47.82 & \\
\hline
\end{tabular}

strategy for Argopecten irradians. In laboratory experiments Tettelbach found an inverse relationship between scallop size (over the range 6 to $62 \mathrm{~mm}$ ) and vulnerability to predation by several crab species, including those used in the present study. Bay scallops did not achieve a partial size refuge from predation until they reached ca $40 \mathrm{~mm}$. Consequently, spatial refuge from predation may be critical for scallop survival at small sizes. The present data clearly demonstrate the value of the eelgrass upper canopy in affording such protection. Settlement and attachment on eelgrass by juvenile bay scallops may, therefore, be viewed as an adaptation for avoiding high mortalities from predators such as crabs, which forage primarily on the bottom.

Yet, despite the demonstrated refuge value of eelgrass, it provides only an ephemeral substrate for scallop attachment due to the rapid turnover rate of blades. Therefore, scallops must continuously reattach to new blades if they are to maintain a position above bottom. Strong currents or physical disturbance may also dislodge attached scallops (Eckman 1987). Therefore, the scallops' ability to exploit a spatial refuge on eelgrass may depend on their ability to regain an above-bottom position following detachment, and on the heightabove-bottom which they successfully attain. Results of this study, however, demonstrated that attachment is strongly size-dependent. Thus we propose the exist- ence of an ontogenetic shift from a spatial refuge from benthic predation in the eelgrass upper canopy at small sizes ( $<$ ca $15 \mathrm{~mm}$ ) to a size refuge from predation at $>30$ to $40 \mathrm{~mm}$, after scallops have relocated to the bottom.

Size-related ontogenetic shifts in refuges from predation have also been observed in freshwater and terrestrial species. Bluegill sunfish Lepomis macrochirus live in vegetated areas when small and move to the pelagic zone of lakes after attaining a partial size refuge from their primary predator, the largemouth bass Micropterus salmoides (Werner \& Hall 1988). Anolis aeneus lizards, which remain in shady areas as subadults and adults, prefer to live in clearings when small, and thus avoid predation by adult Anolis richardi, which only live in the shade (Stamps 1983). In addition, decreasing dependence on vegetation as a refuge from predation with increasing size has been shown for various freshwater and marine fish species (Jackson 1961, Jones 1984, Ebeling \& Laur 1985).

The transition period between the scallops' relocation to the bottom and attainment of a partial size refuge may represent a critical window when postsettlement scallops are especially vulnerable to predation and may experience strong selection for rapid growth and/or predator-avoidance behavior. Tettelbach (1986), in fact, reports more frequent escape swimming behavior for intermediate-sized scallops (15 
to $35 \mathrm{~mm}$ ) than for smaller juveniles and adults. This proposed transition period of high predatory risk occurs during early fall (September to October) and is of short duration since scallop growth is very rapid at this time (10 to $13 \mathrm{~mm} \mathrm{mo}^{-1}$; Tettelbach 1986, García-Esquivel \& Bricelj unpubl.). Predation intensity at this time is expected to vary, however, with eelgrass density and the species composition and size structure of the predator assemblage found at a given site. Future studies will test the existence of this hypothetical critical window of increased vulnerability to predators, and examine its implications for bay scallop stock-enhancement strategies and recruitment of natural populations.

Acknowledgements. We thank J. Christie for his technical assistance throughout the project and for drafting Fig. 1, and $P$. Lawton for his advice in planning the project and for critical reading of early manuscripts. We also thank $C$. Smith of Cornell Cooperative Extension for providing extensive information on scallop reseeding efforts in Long Island embayments; J. K. Winfree of Synthetic Fibers, Inc, for donating the material used in construction of artificial eelgrass; and the Shinnecock Indian Reservation Oyster Project Hatchery, Southampton, New York, and The Clam Farm, Fishers Island, New York, for providing juvenile scallops. W. C. Dennison, C. $H$. Peterson, and 2 anonymous reviewers provided very useful comments on final drafts of this paper. The project was supported by the Living Marine Resources Institute, SUNY at Stony Brook; the NOAA Office of Sea Grant, US Department of Commerce (under grant number NA86AA-DS6045 to the New York Sea Grant Institute); and the Lerner-Gray Fund of the American Museum of Natural History.

\section{LITERATURE CITED}

Adamson, B. A. (1982). Seasonal variation of carbon uptake and translocation by eelgrass (Zostera marina L.) in Great South Bay, New York. M.Sc. thesis, State University of New York at Stony Brook

Ambrose, W. G., Jr, Lin J. (in press). Settlement preference of Argopecten irradians larvae for artificial substrates. In: Shumway, S. E. (ed.) An international compendium of scallop biology and culture. World Aquaculture Soc and Nat. Shellfish. Assoc., Charleston, S. Carolina

Belding, D. L. (1910). A report upon the scallop fishery of Massachusetts. The Commonwealth of Massachusetts, Boston

Bell, J. D., Westoby, M. (1986). Abundance of macrofauna in dense seagrass is due to habitat preference, not predation. Oecologia 68: 205-209

Bell, J. D., Westoby, M., Steffe, A. S. (1987). Fish. larvae settling in seagrass: do they discriminate between beds of different leaf density? J. exp. mar. Biol. Ecol. 111: 133-144

Blundon, J. A., Kennedy, V S. (1982). Refuges for infaunal bivalves from blue crab, Callinectes sapidus (Rathbun), predation in Chesapeake Bay. J. exp. mar. Biol. Ecol. 65: 67-81

Bricelj, V., M., Epp. J., Malouf, R. E. (1987). Intraspecific variation in reproductive and somatic growth cycles of bay scallops Argopecten irradians. Mar Ecol. Prog. Ser 36: 123-137

Caddy, J. F. (1972). Progressive loss of byssus attachment with size in the sea scallop, Placopecten magellanicus (Gmelin) J. exp. mar Biol. Ecol. 9: 179-190
Castagna, M. (1975). Culture of the bay scallop. Argopecten irradians, in Virginia. Mar Fish. Rev. 37(1): 19-24

Coen, L. D., Heck, K. L., Jr, Abele, L. G. (1981). Experiments on competition and predation among shrimps of seagrass meadows. Ecology 62: 1484-1493

Cosper, E. M., Dennison, W. C., Carpenter, E. J., Bricelj, V. M., Mitchell, J.G., Kuenstner, S. H., Colflesh, D., Dewey, M. (1987). Recurrent and persistent brown tide blooms peturb coastal marine ecosystem. Estuaries 10(4): 284-290

Ebeling, A. W., Laur, D. R. (1985). The influence of plant cover on surfperch abundance at an offshore temperate reef. Environ. Biol. Fish. 12: 169-179

Eckman, J. E. (1987). The role of hydrodynamics in recruitment, growth, and survival of Argopecten irradians (L.) and Anomia simplex (D'Orbigny) within eelgrass meadows. J exp. mar. Biol. Ecol. 106: 165-191

Eckman, J. E., Peterson, C. H., Cahalan, J. A. (1989). Effects of flow speed, turbulence, and orientation on growth of juvenile bay scallops Argopecten irradians concentricus (Say). J. exp. mar. Biol. Ecol. 132: 123-140

Eggleston, D. B. (1990). Foraging behavior of the blue crab, Callinectes sapidus, on juvenile oysters, Crassostrea virginica: effects of prey density and size. Bull. mar Sci. 46(1): $62-82$

Flagg, P. J., Malouf, R. E. (1983). Experimental plantings of juveniles of the hard clam Mercenaria mercenaria (Linné) in the waters of Long Island, New York. J. Shellfish Res $3(1): 19-27$

Gutsell, J. S. (1930). Natural history of the bay scallop. U.S Bur. Fish. Bull. 46: 569-632

Hamilton, P. V. (1976). Predation on Littorina irrorata (Mollusca: Gastropoda) by Callinectes sapidus (Crustacea: Portunidae). Bull. mar. Sci. 26: 403-409

Heck, K. L., Jr, Orth, R. J. (1980). Seagrass habitats: the roles of habitat complexity, competition and predation in structuring associated fish and motile macroinvertebrate assemblages. In: Kennedy, V S. (ed.) Estuarine perspectives. Academic Press, New York, p. 449-464

Heck, K. L., Jr, Thoman, T. A. (1981). Experiments on predator-prey interactions in vegetated aquatic habitats. J. exp. mar Biol. Ecol. 53: 125-134

Hickey, M. I (1977). Age, growth, reproduction and distribution of the bay scallop. Aequipecten irradians irradians (Lamarck), in three embayments in eastern Long Island, New York, as related to the fishery. M.Sc. thesis, C. W Post College, Long Island University, New York

Jackson, P. B. N. (1961). The impact of predation, especially by the tiger-fish (Hydrocyon vittatus Cast.) on African freshwater fishes. Proc zool. Soc. Lond 136: 603-622

Jones, G. P. (1984). The influence of habitat and behavioural interactions on the local distribution of the wrasse, Pseudolabrus celidotus. Environ. Biol. Fish. 10: 43--58

Keats, D. W. (1990). Food of winter flounder Pseudopleuronectes americanus in a sea urchin dominated community in eastern Newfoundland. Mar Ecol. Prog. Ser. 60: 13-22

Leber, K. M. (1985). The influence of predatory decapods, refuge, and microhabitat selection on seagrass communities. Ecology 66: 1951-1964

Main, K. L. (1987). Predator avoidance in seagrass meadows: prey behavior, microhabitat selection, and cryptic coloration. Ecology 68: 170-180

Morgan, D. E., Goodsell, J., Matthiessen, G. C., Garey, J., Jacobson, P. (1980). Release of hatchery-reared bay scallops (Argopecten irradians) onto a shallow coastal bottom in Waterford, Connecticut. Proc. Wld Maricult. Soc. 11 $247-261$

Nelson, W. G. (1979). Experimental studies of selective preda- 
tion on amphipods: consequences for amphipod distribution and abundance. J. exp. mar Biol. Ecol. 38: 225-245

Orth, R. J., Heck, K. L., Jr, van Montfrans, J. (1984). Faunal communities in seagrass beds: a review of the influence of plant structure and prey characteristics on predator-prey relationships. Estuaries $7(4 \mathrm{~A}): 339-350$

Peterson, C. H. (1982). Clam predation by whelks (Busycon spp.): experimental tests of the importance of prey size, prey density, and seagrass cover Mar Biol. 66: 159-170

Peterson, C. H. (1990). On the role of ecological experimentation in resource management: managing fisheries through mechanistic understanding of predator feeding behaviour. In: Hughes, R. N. (ed.) Behavioural mechanisms of food selection. NATO ASI Series, Vol. G 20. Springer-Verlag, Berlin, p. 821-846

Peterson, C. H., Summerson, H. C., Fegley, S. R., Prescott, R. C. (1989). Timing, intensity and sources of autumn mortality of adult bay scallops Argopecten irradians concentricus Say. J. exp. mar Biol. Ecol. 127 121-140

Pohle, D G. (1990). The role of eelgrass, Zostera marina, as a refuge from benthic predators for juvenile bay scallops, Argopecten irradians. M.Sc thesis, State University of New York at Stony Brook

Rozas, L. P., Odum, W. E. (1988). Occupation of submerged aquatic vegetation by fishes: testing the roles of food and refuge. Oecologia 77:101-106

Ryer, C. H. (1988). Pipefish foraging: effects of fish size, prey size and altered habitat complexity. Mar Ecol. Prog. Ser 48: $37-45$

Sokal, R. R., Rohlf, F. J. (1981). Biometry. The principles and practice of statistics in biological research, 2nd edn. W. H. Freeman \& Co., New York

Stamps, J. A. (1983). The relationship between ontogenetic habitat shifts, competition and predator avoidance in a juvenile lizard (Anolis aeneus). Behav. Ecol. Sociobiol. 12: 19-33

Stewart, L. L., Auster, P. J., Zajak, R. (1981). Investigation on

This article was presented by C. H. Peterson, Morehead City, N. Carolina, USA the bay scallop. Argopecten irradians, in three eastern Connecticut estuaries. June 1980 - May 1981 Final Report, U.S. Dept of Commerce, NOAA, Milford, Connecticut

Stoner, A. W. (1982). The influence of benthic macrophytes on the foraging behavior of pinfush, Lagodon rhomboides (Linnaeus). J. exp. mar Biol. Ecol. 58: 271-284

Summerson, H. C., Peterson, C. H. (1984). Role of predation in organizing benthic communities of a temperate-zone seagrass bed. Mar Ecol. Prog. Ser 15: 63-77

Summerson, H. C., Peterson, C. H. (1990). Recruitment fallure of the bay scallop. Argopecten irradians concentricus, during the first red tide, Ptychodiscus brevis, outbreak recorded in North Carolina. Estuaries 13(3): 322-331

Tettelbach, S. T. (1986). Dynamics of crustacean predation on the northern bay scallop. Argopecten irradians irradians. Ph.D. thesis, University of Connecticut

Thayer, G. W., Stuart, H. H. (1974). The bay scallop makes its bed of seagrass. Mar Fish. Rev. 36 (7): 27-30

Vaughn, C. C., Fisher, F. M. (1988). Vertical migration as a refuge from predation in intertidal marsh snails: a field test. J. exp. mar. Biol. Ecol. 123: 163-176

Virnstein, R. W., Curran, M. C. (1986). Colonization of artificial seagrass versus time and distance from source. Mar. Ecol. Prog. Ser. 29: 279-288

Warren, J. H. (1985). Climbing as an avoidance behaviour in the salt marsh periwinkle, Littorina irrorata (Say). J. exp. mar. Biol. Ecol. 89: 11-28

Werner, E. E., Hall, D. J. (1988). Ontogenetic habitat shifts in bluegill: the foraging rate-predation risk trade-off. Ecology 69: 1352-1366

Wilson, K. A., Heck, K. L., Jr, Able, K. W. (1987). Juvenile blue $\mathrm{crab}$, Callinectes sapidus, survival: an evaluation of eelgrass, Zostera marina, as refuge. Fish. Bull. U.S. 85(1): $53-58$

Yamamoto, G. (1960). Mortalities of the scallop during its life cycle. Bull. mar biol. Stn Asamushi 10(2): 149-152

Manuscript first received: September 26, 1990

Revised version accepted: April 26, 1991 